\title{
Assessment of Bacterial and Fungal Contamination in Public Swimming Pools in Shahrekord - IRAN
}

Shirin Saberianpour ${ }^{1^{*}}$, Hassan Momtaz ${ }^{2}$, Fahimeh Ghanbari ${ }^{3}$ and Farhad Mahmodi ${ }^{2}$

${ }^{1}$ Young Researchers and Elite Club, Shahrekord Branch, Islamic Azad University, Shahrekord, Iran

${ }^{2}$ Department of Microbiology, Faculty of Basic Sciences, Shahrekord Branch, Islamic Azad University, Shahrekord, Iran

${ }^{3}$ Department of Microbiology, Faculty of Basic Sciences, Islamic Azad University, Flavarjan, Isfahan, Iran

\section{Abstract}

Background and Purpose: The swimming pool is an important center of entertainment for the public. Pool area is very suitable for the transmission of various diseases, especially fungal and bacterial contamination. The aim of this study was to identify the fungus Candida Albicans, Aspergillus and Penicillium and different bacterial elements in public swimming pools in the fall of 2014.

Methods: In this descriptive study, five public swimming pools were investigated in Shahrekord to examine the water contamination for fungal infection in the swimming pools during autumn of 2014. Sampling was done in two different times, and all the microbiological, chemical, and physical tests were done through standard methods. Test parameters included counting and identification of bacteria and fungi, and assessment of the remaining chlorine and $\mathrm{pH}$ level.

Results: The results revealed that the average $\mathrm{pH}$ and chlorine levels were 7.8 and $1.62 \mathrm{mg} / \mathrm{L}$, respectively. The isolated sample of bacteria included Escherichia coli, Pseudomonas aeruginosa, Staphylococcus aureus, and Staphylococcus epidermidis. Other strains of bacteria, i.e. Bacillus cereus, Enterobacter faecalis, Enterobacter aerogenes, and Clostridium perfringens were reported negative. Of 21 strains sampled from five swimming pools in Shahrekord, Penicillium species with $9.52 \%$ percent, Candida albicans with 4.76 percent, and Aspergillus species with9.5 \% were isolated.

Conclusions: As public swimming pools can be contaminated with different types of parasites and also fungi, observing personal and environmental hygiene, and following standards for remaining free chlorine in water can help reduce the fungal contamination. Considering the fact that most of the bacteria isolated from the pool water in the study contained Escherichia coli, we can conclude that improving the environment and hygienic behavior of the swimmers can be effective in reducing the bacterial contamination in the pools.

Keywords: Swimming pool; Fungal contamination; Bacterial contamination; Remaining free chorine

\section{Introduction}

Public swimming pools are among the water recreation centers that attract many fans to themselves. However, microbial and bacterial contaminations in water and the environment of pools can cause ear and eye infections, digestive system infections, skin diseases, and infections of the upper respiratory tract in swimmers, especially those with immune system deficiencies [1-3]. Pool water is exposed to contamination from body fat and waste material such as nasal secretions, saliva, sweat, fecal, urine, and body lotions and creams. Moreover, hair and dust from the surrounding environment can also cause water contamination. The contamination in swimming pools is divided into three categories of physical, chemical, and microbial contamination. Studies have shown that pool water can act as a medium to spread fungal diseases among the swimmers. Swimmers, who swim at contaminated pools, are prone to fungal infection, as the exterior ear, and toe intervals etc. have a relative level of moisture. Previous studies have revealed that physic-chemical factors such as $\mathrm{pH}$ are very influential. If the water $\mathrm{pH}$ is alkaline, chlorine antiseptic performance will decrease. Pools which have a high temperature provide the grounds foe fungal contamination. Moreover, other microorganisms such as fecal based bacteria (Escherichia coli), and Pseudomonas aeruginosa, Fecal streptococcus, and Marinum are among other microorganisms that are found to contaminate water in swimming pools $[4,5]$.

Based on the studies done on the water $\mathrm{n}$ swimming pools within and outside Iran, it has been revealed that Pseudomonas aeruginosa, fecal streptococci and fecal coliforms are relatively contaminant [6-
14]. According to the mentioned studies, defining hygiene standards to control water-based diseases is one of the most influential factors to ensure the safety of the pool water and the health of swimmers. Thus, investigating the hygienic criteria of the water in swimming pools seems necessary. Considering the new criteria, physical factors including the $\mathrm{pH}$, remaining free chlorine, and temperature are among the most important factors to control the quality and quantity of microbial contamination. The current study aims at identifying a number of contaminant bacteria strains and investigating the effect of $\mathrm{pH}$ and the remaining free chlorine on Aspergillus, Penicillum, and Candida albicans strains in swimming pools in Shahrekord.

\section{Methods and Materials}

The current article is a descriptive-cross sectional study done to investigate the bacterial contamination in the swimming pools in the fall of 2014, in Shahrekord. 21 samples were taken from low-depth and

*Corresponding author: Shirin Saberianpour, Young Researchers and Elite Club, Shahrekord Branch, Islamic Azad University, Shahrekord, Iran, Tel: 98214486 5179 ; E-mail: saberi_shirin@yahoo.com

Received October 18, 2015; Accepted December 04, 2015; Published December 11, 2015

Citation: Saberianpour S, Momtaz H, Ghanbari F, Mahmodi F (2015) Assessment of Bacterial and Fungal Contamination in Public Swimming Pools in Shahrekord IRAN. J Trop Dis 4: 190. doi:10.4172/2329891X.1000190

Copyright: $(2015$ Saberianpour S, et al. This is an open-access article distributed under the terms of the Creative Commons Attribution License, which permits unrestricted use, distribution, and reproduction in any medium, provided the original author and source are credited. 
5 meter high depth sections of the pools at two different times. In order to assess the $\mathrm{pH}$ and the level of remaining free chlorine, Merck-11134 kit was used. To isolate the sample from the water, $1000 \mathrm{~mL}$ sterile bottles were used. The samples were transferred to the Research Laboratory of Microbiology, at Islamic Azad University of Shahrekord. In order to neutralize the remaining chlorine, the samples were passed through 0.45 micron sterile syringe filters, and then $2 \mathrm{~mL}$ lysis buffer was forced through the filters. Applying phenol and chloroform, DNA was extracted from the samples. The extracted DNA was then categorized based on 18SrRNA primers. Each bacterium was isolated and investigated applying multiple PCR method, using temperature program including an initial cycle of $94^{\circ} \mathrm{C}$ for $6 \mathrm{~min}$ and 34 repeated cycles of $95^{\circ} \mathrm{C}$ for $1 \mathrm{~min}, 58^{\circ} \mathrm{C}$ for $1 \mathrm{~min}$, and $72^{\circ} \mathrm{C}$ for $1 \mathrm{~min}$, and a final cycle of $72^{\circ} \mathrm{C}$ for $8 \mathrm{~min}$. The data on this is given in Table 1 . To track the PCR amplifications, gene fragments were analyzed by Agarose gel electrophoresis. 15 microliter of the PCR product from each stage of the experiment was exposed to 100 BP DNA marker with 1.5\% Agarose gel in 130 volts for about 45 minutes. The resulting gel was then viewed with UV Illuminator and the observed BP bands of 158, 357, and 570 were related to fungal species of Candida albicans, Aspergillus species and Penicillium species, respectively.

\section{Results}

The findings of physiochemical investigation of the water from 5 swimming pools in Shahrekord revealed that the average remaining free chlorine in the water was $1.62 \mathrm{mg} / \mathrm{L}$, and the average $\mathrm{pH}$ was 7.8 . The results showed that the highest bacterial contamination was for Escherichia coli with 95.23 percent. The prevalence of other bacteria species, including Staphylococcus aureus, Pseudomonas aeroginosa and Staphylococcus epidermidis was 19.04, 9.52 and 4.76 respectively. Existence of other bacteria, such as Bacillus cereus, Enterococcus faecalis, Enterobacter aerogenes and Colestridium perfringenes was reported negative [15-20].

The findings of the first physiochemical parameters analysis of the isolated bacterial species from the studied pools are given in Table 3.

\begin{tabular}{|c|c|c|c|}
\hline Bacterium & Primer (5'- 3') & $\begin{array}{l}\text { Length } \\
\text { bp }\end{array}$ & Reference \\
\hline \multirow[t]{2}{*}{ Escherichia coli } & AGAGTTTGATCCTGGCTCAG & 270 & 15 \\
\hline & GGTTACCTTGTTACGACTT & & \\
\hline \multirow[t]{2}{*}{$\begin{array}{c}\text { Pseudomonas } \\
\text { aeruginosa }\end{array}$} & AGAGTRTGATCMTYGCTWAC & 136 & 16 \\
\hline & CGYTAMCTTWTTACGRCT & & \\
\hline \multirow[t]{2}{*}{ Bacillus cereus } & TGCAACTGTATTAGCACAAGC T & 533 & 17 \\
\hline & TACCACGAAGTTTGTTCACTACT & & \\
\hline \multirow[t]{2}{*}{$\begin{array}{c}\text { Staphylococcus } \\
\text { aureus }\end{array}$} & CGA TTC CCT TAG TAG CGG CG & 1267 & 18 \\
\hline & CCAATC GCA CGC TTC GCC & & \\
\hline \multirow[t]{2}{*}{$\begin{array}{c}\text { Staphylococcus } \\
\text { epidermidis }\end{array}$} & AGAGTTTGATCCTGGCTCAG & 550 & 19 \\
\hline & TACCGCGGCTGCTGGCAC & & \\
\hline \multirow[t]{2}{*}{ Enterococus fecalis } & $\begin{array}{c}\text { GTT TAT GCC GCA TGGCAT } \\
\text { AAG AG }\end{array}$ & 310 & 20 \\
\hline & CCG TCA GGG GAC GTTCAG & & \\
\hline \multirow[t]{2}{*}{$\begin{array}{c}\text { Enterobacter } \\
\text { aerogenes }\end{array}$} & $\begin{array}{c}\text { ATG TCT GGG AAA CTG CCT } \\
\text { GAT GGA }\end{array}$ & & 21 \\
\hline & $\begin{array}{c}\text { ACT TTG GTC TTG CGA CGT } \\
\text { TAT GCG }\end{array}$ & & \\
\hline \multirow[t]{2}{*}{$\begin{array}{l}\text { Clostridium } \\
\text { perfringens }\end{array}$} & AAAGATGGCATCATCATTCAAC & 279 & 22 \\
\hline & TACCGTCATTATCTTCCCCAAA & & \\
\hline
\end{tabular}

Table 1: Primers used for gene detection of bacterial species.
The highest level of remaining free chlorine is for pool number 4 , and the lowest is for pools number 1 and 5. Among 21 studied samples from the pools, fungal species of Penicillium species with $9.52 \%$ percent, Candida albicans with 4.76 percent, and Aspergillus species with 9.52 percent were isolated from water. The results of the second and third sampling for each pool are given in Tables 2 and 3. The average remaining chlorine was $1.73 \mathrm{mg} / \mathrm{L}$ and the $\mathrm{pH}$ was in suitable range. During the second sampling, which was done 30 days after the first time, the highest level of remaining free chlorine was in pool number 4 , and the lowest in pool number 5. Compared to the first sampling, the amount of bacterial contamination in pools number 1 and 2 was reduced which might be due to the increase in the level of remaining free chlorine in water. In average, the level of free chlorine and $\mathrm{pH}$ in the water in these pools was in an acceptable range [21-24].

\section{Discussions and Conclusions}

Swimming in the swimming pools is very advantageous to public health and welfare. Although, at the first glance, pool water cannot be considered as an ideal fungal infection transmitter, it may cause certain threats to the swimmers [25]. Nevertheless, the physical environment of swimming pool is highly humid and warm, which makes it a suitable environment for fungi spread and cultivation. Most of Saprophyte fungi, such as different species of Aspergillus, Penicillium, Mucor and Rizopus grow easily in humid and warm environments [26,27].

During the current study, Penicillium species with $9.52 \%$ percent, Candida albicans with 4.76 percent, and Aspergillus species with 9.52 percent were reported positive among the 21 samples taken from the 5 swimming pools in Shahrekord. According to the results, $\mathrm{pH}$ was in an acceptable range and there was no statistically significant difference between the level of remaining chlorine in the low-depth and deep sections of the pools. Among similar studies done in different cities in recent years, we can refer to Shadzi et.al. in which, using filtration and carpet sampling methods, fungal contamination was investigated in four public swimming pools in Isfahan. A sum of 60 samples were used to isolate the studied fungi from water and the surrounding environment of the pools (cloak room, foot wash, and the shower) in different seasons. The most prevalent fungi were in order cladosporium with $34.9 \%$, Penicillium with $31.2 \%$, Rizopus with 9.7\%, Aspergillus With $9.2 \%$, Yeasts With $6.2 \%$ and unidentified string fungi with $8.8 \%$. Moreover, Trichophyton mentagrophytes was isolated from 9 cloak rooms and showers [28]. The results of the mentioned study are almost identical to those of the current study. In another study done by Jafari et al. in indoor pools in Yazd, a total of 720 samples were cultured and the study revealed that $68.7 \%$ of the samples were contaminated with one or more fungi, which is way beyond the results of this study [29]. The study done by Shahriari et al. on the prevalent microbial criteria in the swimming pools in Gorgan revealed that there was a relative

\begin{tabular}{|c|c|c|c|}
\hline Fungus & Primer (5'- 3') & $\begin{array}{l}\text { Length } \\
\text { bp }\end{array}$ & Reference \\
\hline \multirow[t]{2}{*}{ Candida albicans } & $\begin{array}{c}\text { GCC GGT GAC GAC GCTCCA } \\
\text { AGA GCTG }\end{array}$ & 158 bp & 23 \\
\hline & $\begin{array}{c}\text { CCG TGT TCAATT GGGTAT } \\
\text { CTC AAG C }\end{array}$ & & \\
\hline \multirow[t]{2}{*}{ Aspergillus species } & CGGCCCTTAAATAGCCCGGTC & $357 b p$ & 24 \\
\hline & ACCCCCCTGAGCCAGTCCG & & \\
\hline \multirow[t]{2}{*}{ Penicillium species } & TCCGTAGGTGAACCTGCGG & $570 b p$ & 25 \\
\hline & TCCTCCGCTTATTGATATGC & & \\
\hline
\end{tabular}

Table 2: Primers used for gene detection of fungal species. 


\begin{tabular}{|l|l|l|l|l|l|l|l|}
\hline $\begin{array}{l}\text { Penicillium } \\
\text { species }\end{array}$ & $\begin{array}{l}\text { Aspergillus } \\
\text { species }\end{array}$ & $\begin{array}{l}\text { Candida } \\
\text { albicans }\end{array}$ & $\begin{array}{l}\text { Residual } \\
\text { chlorine } \\
\text { ppm }\end{array}$ & PH & & Pool \\
\hline+ & + & - & 0.6 & favorable & Shallow & 1 \\
\hline- & - & - & & & Deep & \\
\hline- & - & - & 2 & favorable & Shallow 2 \\
\hline- & - & - & & & Deep & \\
\hline- & - & - & 1.5 & favorable & Shallow 3 \\
\hline- & - & - & & & Deep & \\
\hline+ & - & + & 2.5 & favorable & children & \\
\hline- & - & - & 2.5 & favorable & Shallow 4 \\
\hline- & - & - & & & Deep & \\
\hline- & - & - & 1 & favorable & Shallow 5 \\
\hline- & - & - & & & Deep & \\
\hline
\end{tabular}

Table 3: Determine amount offree residual chlorine, $\mathrm{PH}$ and fungal contamination.

\begin{tabular}{|c|c|c|c|c|c|c|}
\hline $\begin{array}{c}\text { Penicillium } \\
\text { species }\end{array}$ & $\begin{array}{c}\text { Aspergillus } \\
\text { species }\end{array}$ & $\begin{array}{c}\text { Candida } \\
\text { albicans }\end{array}$ & $\begin{array}{c}\text { Residual } \\
\text { chlorine } \\
\text { ppm }\end{array}$ & PH & & Pool \\
\hline- & - & - & 2 & favorable & Shallow & 1 \\
\hline- & - & - & & & Deep & \\
\hline- & - & - & 2 & favorable & Shallow & 2 \\
\hline- & - & - & & & Deep & \\
\hline- & - & - & 2 & favorable & Shallow & 3 \\
\hline- & - & - & & & Deep & \\
\hline- & - & - & 2.5 & favorable & Shallow & 4 \\
\hline- & - & - & & & Deep & \\
\hline- & + & - & 0.5 & favorable & Shallow & 5 \\
\hline- & - & - & & & Deep & \\
\hline
\end{tabular}

Table 4: Determine amount offree residual chlorine, $\mathrm{PH}$ and fungal contamination.

contamination in the samples taken from pools without remaining free chlorine. However, there was no statistical significant difference between the levels of remaining free chlorine and the contaminations in the water of swimming pools in Shahrekord [30]. The current study, along with other studies done in Iran, show that measuring some physicochemical criteria can, to a great extent, help prevent and control microbial and fungal factors in the pool water. Findings also suggest that the level of remaining free chlorine in the pool water must be in the range of 1 to $2 \mathrm{mg} / \mathrm{L}$, or otherwise some fungi may get the opportunity to grow [31]. In our study, the average free chlorine level was 1.73 $\mathrm{mg} / \mathrm{L}$, which is acceptable. Feuerman et al. suggested that there was no Dermatophyt contamination in the water samples from the pools which were washed with chlorine [32]. Another study done by Roy et al. in the U.S. concluded that whenever the $\mathrm{pH}$, remaining free chlorine, and the swimming load of a pool is given, a perfect judgment can be made about the contamination in water with $95 \%$ certainty [33]. In the current study all the swimming pools had normal $\mathrm{pH}$ levels. Based on the findings of the current study, we can conclude that although swimming pools can be contaminated with different microbial factors, the current disinfection methods are based on the standards. Taking a shower and washing the body with soap, as well as observing the standards of $\mathrm{pH}$ and free remaining chlorine are amongst the other physical factors contributing to the prevention of microbial and fungal contaminations in swimming pools. Studies indicate that swimming pools play a significant role in spreading bacterial, fugal, viral, and parasitic diseases [34]. The most prevalent ways of microbial spread in pools are exposure and swallowing water from the sections that are not sufficiently disinfected. Skin contamination in swimmers and lack of precise disinfection in pools can help spread diseases [35].

In the current study, the average $\mathrm{pH}$ was 7.8 . The acceptable $\mathrm{pH}$ for swimming pool water is 7.2 to 8 . In low $\mathrm{pH}$ environment, problems such as itch, chlorine loss, skin spots, and sore eyes can occur in swimmers . According to national standards, $\mathrm{pH}$ should be between 7.2 to 8 , and the level of free remaining chlorine should be 1 to $2 \mathrm{mg} / \mathrm{L}$ [36]. In the current study, the level of free chlorine was in the acceptable range.

The current study involved 21 samples, in which Escherichia coli with 95.23\% had the highest prevalence rate among the water contaminants. Existence of other bacterial contaminants such as Pseudomonas aeroginosa. (9.52\%), Staphylococcus aureus (19.04\%), Staphilococus epidermitis (4.76\%) was reported positive. However, existence of other bacterial contaminants such as Bacillus cereus, Enterococus fecalis, Enterobacter aerogenes and Colestridium perfringenes was reported negative. Findings show that in all cases, Escherichia coli contamination has exceeded the standards. As Escherichia coli can enter water from organic, soil, and bodily waste origins including contaminated environment, swimsuits, or fecal, positive existence of Escherichia coli indicates the existence of other bacteria. Escherichia coli prevalence and its spread to swimmers can cause severe diarrhea and digestive system problems.

In another study done in Switzerland, Barben et al. argued that from a sum of 117 samples taken from 46 swimming pools during the summer, 3 samples were contaminated with Pseudomonas aeroginosa. This study also revealed that the mentioned swimming pools were insufficiently disinfected [37].

Staphylococcus aureus is the cause of dermal and eye infections, exterior ear inflammation, uterine infections and Impetigo, and is found in nasal mucosa, on skin, and in meconium [38]. Letting out mucosa from nose, ears, and throat into water, involuntary urinating, and the exposure of skin contaminations to water increases the chances of getting Staphylococcus aureus related diseases [39]. According to the current study, the prevalence of the mentioned bacterium was $19.04 \%$. Another microorganism criterion related to low quality of recreational water is fecal-based Enterococcus. These microorganisms are found in the intestines of human and warm-blooded animals and is used to track down fecal-based contamination. During the present study, no fecal Enterococcus was found. Heterotroph bacteria including Enterobacter are among the opportunist pathogens, and the maximum allowed number of them is 200 per each $\mathrm{mL}$ of water [40]. Statistical analysis of the data revealed that there is a reverse relationship between the number of heterotrophic bacteria and the remaining free chlorine ( $\mathrm{P}$ value $=0.031$ ). The number of disease inducing factors found in the second sampling, which was done 30 days later, decreased in pools number 1 and 2 . This is due to the increase in the level of remaining free chlorine in the water of these two pools in the second sampling. In order to increase the quality of the water in swimming pools, and to prevent the spread of diseases, observing hygienic standards, including improving the environment of the pool, taking showers, and washing the body with soap prior to the entrance into the pool is highly suggested. In addition, swimmers must be trained to observe the hygienic standards before entering, and while swimming in the pool. 
Citation: Saberianpour S, Momtaz H, Ghanbari F, Mahmodi F (2015) Assessment of Bacterial and Fungal Contamination in Public Swimming Pools in Shahrekord - IRAN. J Trop Dis 4: 190. doi:10.4172/2329-891X.1000190

\section{References}

1. Dumani A, Yoldas O, Yilmaz S, Koksal F, Kayar B, et al. (2012) Polymerase chain reaction of enterococcus faecalis and candida albicans in apical periodontitis from Turkish patients. Journal of clinical and experimental dentistry 4: e34.

2. Rabi A, Khader Y, Alkafajei A, Aqoulah AA (2007) Sanitary conditions of public swimming pools in Amman, Jordan. International Journal of Environmental research and Public health 4: 301-306.

3. Schets FM, Schijven JF, de Roda Husman AM (2011) Exposure assessment for swimmers in bathing waters and swimming pools. Water research 45: 2392 2400.

4. Itah AY, Ekpombok MU (2004) Pollution status of swimming pools in southsouth zone of south-eastern Nigeria using microbiological and physicochemical indices. Southeast Asian J Trop Med Public Health 35: 488-493.

5. Ehrampoosh MH, Jafari AA, Rahimi S, Ghaneian MT, Khabiri F (2011) Study of Dermatophytic Fungal Species in Covered Swimming Pools in Yazd, Iran. Health System Research 7: 373-380.

6. Nikaeen M, Hatamzadeh M, Vahid Dastjerdi M, Hassanzadeh A, Mosav $Z$, et al. (2010) An investigation on physical, chemical and microbial quality of Isfahan swimming pool waters on standard indicators. Journal of Isfahan Medical School 28: 346-356.

7. Rasti S, Assadi MA, Iranshahi L, Saffari M, Gilasi HR, et al. (2012) Assessment of Microbial Contamination and PhysicochemicalCondition of Public Swimming Pools in Kashan, Iran. Jundishapur J Microbiol 5: 450-455.

8. Neghab M, Gorji HA, Baghapour MA, Rajaiifard AR (2004) Survey on water contamination of swimming pools in Shiraz. Scientific Journal of Kurdestan University of Medical Sciences 31: 41-49.

9. Nanbakhsh H, Diba K, Hazrati Tape K (2005) A survey on fungal contamination and some physicochemical parameters of indoor pools in Orumieh. Scientific Journal of Kurdestan University of Medical Sciences 10: 26-35.

10. Nourian AA, Badali $H$, Hamzei $H$ (2004) A survey on fungal contamination of indoor pools in Zanjan in 2003. Scientific Journal of Zanjan University of Medical Sciences 48: 43-48.

11. Mehdi Nejad MH (2003) The determination of quality of healthy indicators in swimming pools in Gorgan. J Gorgan Univ Med Sci 5: 84-97.

12. Azizjalali MH, Behrangi E (2009) Study of the Prevalence of Tinea Pedis in Swimmers of the West Pools of Tehran in 2007. Journal of Iran University of Medical Sciences 16: 94-102.

13. Kazemifard H, Jandaghi GR, Safdari M, Azizifar M (2006) The study of Dermatophytic infections in public swimming pools of Qom city during 2004. Journal of Arak University of Medical Sciences 9: 1-6.

14. Dindarlu K, Soleimani Ahmadi M, Zare S, Abdi H, Heidari M (2005) Sanitary condition of swimming pool in Bandarabbas in second half of 2003. Medical Journal of Hormozgan 9: 41-46

15. James $G$ (2010) Universal bacterial identification by PCR and DNA sequencing of 16S rRNA gene. In PCR for clinical microbiology 209-214.

16. Tripathi P, Banerjee G, Gupta MK, Saxena S, Ramteke PW (2013). Assessment of phylogenetic affiliation using 16S rRNA gene sequence analysis for Pseudomonas aeruginosa in patients of lower respiratory tract infection. The Indian journal of medical research 138: 557

17. Das S, Surendran PK, Thampuran N (2009) PCR-based detection of enterotoxigenic isolates of Bacillus cereus from tropical seafood. Indian $\mathrm{J} \mathrm{Med}$ Res 129: 316-320

18. Moussa I, Shibl AM (2009) Molecular characterization of methicillin-resistan Staphylococcus aureus recovered from outpatient clinics in Riyadh, Saudi Arabia. Saudi medical journal 30: 611-617.

19. Hong T, Li X, Wang J, Sloan C, Cicogna C (2007) Sequential linezolid-resistan Staphylococcus epidermidis isolates with G2576T mutation. Journal of clinical microbiology 45: 3277-3280.
20. Veleba M, De Majumdar S, Hornsey M, Woodford N, Schneiders T (2013) Genetic characterization of tigecycline resistance in clinical isolates of Enterobacter cloacae and Enterobacter aerogenes. Journal of Antimicrobial Chemotherapy 68: 1011-1018.

21. Yoo HS, Lee SU, Park KY, Park YH (1997) Molecular typing and epidemiological survey of prevalence of Clostridium perfringens types by multiplex PCR. Journal of Clinical Microbiology 35: 228-232.

22. Melchers WJ, Verweij PE, Van den Hurk $P$, Van Belkum A, De Pauw BE, et al. (1994) General Primer-Mediated Pcr For Detection Of Aspergillus Species Journal Of Clinical Microbiology 32: 1710-1717.

23. Demirel R, Sariozlu NY, İlhan S (2013) Polymerase Chain Reaction (PCR) Identification of Terverticillate Penicillium Species Isolated from Agricultural Soils in Eskişehir Province Braz Arch Biol Technol 56: 980-984.

24. Nourian AA, Badali $H$, Hamzhei $H$ (2006) Fungal contamination in indoor swimming pools in Zanjan-Iran 2005. Pak J Bio Sci 9: 2524-2527.

25. Hilmarsdottir I, Haraldsson H, Sigurdardottir A, Sigurgeirsson B (2005) Dermatophytes in a swimming pool facility: difference in dermatophyte load in men's and women's dressing rooms. Acta Derm Venereol 85: 267-268.

26. Rafiei A, Amirrajab N (2010) Fungal Contamination of Indoor Public Swimming Pools, Ahwaz, South-west of Iran. Iran J Publ Health 39: 124-128.

27. Shadzi SH., Pour MH., Zare A, Chadeganipour M(2001)Fungal contaminations in four swimming pools in isfahan, iran. Iran J Basic Med Sci 4: 9-12.

28. Jafari A, Ghaneian M, Ehrampoush M, Zarei S (2011) Survey of Fungal Contamination in Surfaces of Yazd indoor Swimming Pools in. Toloo-EBehdasht 12: 61-69.

29. Shahriari A, Nafez AH, Norouzi S, Heidari M (2012) Investigation of Common Microbial Indicators in Swimming Pool of Gorgan City. J Health Hyg 2: 17-26.

30. Nichols G (2005) Infection risks from water in natural and man-made environments. Euro Surveill 11: 76-78.

31. Feuerman EJ, Alteras I, Lehrer N (1977) On the occurrence of pathogenic dermatophytes in some swimming-pools from Tel Aviv area. Castellania 5: 121 122.

32. Paul RA (1972) An environmental mode for swimming pool bacteriology. Am J Public Health 62: 770-772.

33. Merz M, Krastl G, Kühl S, Filippi A (2011) A survey of Swiss swimming poo attendants' knowledge of first-aid treatment after lip and dental injuries. Schweiz Monatsschr Zahnmed 121: 528-536.

34. Brewster DH, Brown MI, Robertson D, Houghton GL, Bimson J, et al. (1994) An outbreak of Escherichia coli $\mathrm{O} 157$ associated with a childrenss paddling pool. Epidemiol Infect 112: 441-447.

35. Seyfried PL, Fraser DJ (1980) Persistence of Pseudomonas aeruginosa inchlorinated swimming pools. Can J Microbiol 26: 350-355.

36. Mehdinezad MH (2003) The determination of quality of healthy indicators in swimming pools in Gorgan. J Gorgan Uni Med Sci 5: 89-95.

37. Barben J, Hafen G, Schmid J (2005) Pseudomonas aeruginosa in public swimming pools and bath-room water of patients with cystic fibrosis. J Cyst Fibros 4: 227-231

38. John DT, Petri WA (2006) Markell and Voge,s Medical parasitology. 9th edn. Markell and Voge's Medical Parasitology, Tulsa.

39. Gregori NZ, Fechter HP, Miller D, Perez E, Diaz M (2003) A Comparison of Bacteria Present in South Florida Ocean and Pool Water with Known Ocular Pathogens. Invest Ophthalmol Vis Sci 44: 1428.

40. Casanovas-Massana A, Blanch AR (2013) Characterization of microbial populations associated with natural swimming pools. Int $\mathrm{J}$ Hyg Environ Health 216: 132-137. 